Acta Agroph., 2018, 25(3), 329-341

doi: $10.31545 /$ aagr/93734

\title{
CHEMICAL COMPOSITION OF COMPOST FROM MUNICIPAL WASTE IN THE CONTEXT OF USE AS FERTILISER
}

\author{
Marcin Becher, Barbara Symanowicz, Dawid Jaremko, Ewa Trzcińska \\ Department of Soil Science and Plant Nutrition, Siedlce University of Natural Sciences and Humanities \\ ul. Konarskiego 2, 08-110 Siedlce, Poland \\ e-mail: marcin.becher@uph.edu.pl
}

\begin{abstract}
A b stract. The study addresses the problem of assessment of the chemical properties of compost produced on the basis of organic fraction of municipal waste, including the quantity and quality of organic matter. Six composts originating from central-eastern Poland were included in the research. The following analyses were performed: $\mathrm{pH}$; salinity; content of $\mathrm{C}, \mathrm{N}, \mathrm{P}, \mathrm{K}$ and heavy metals, fractional composition of organic matter (after decalcification, bitumens, fulvic acids, humic acids and post-extraction residue) and properties of humic acids (elemental composition and spectrophotometric properties). The analysed composts were characterised by a similar chemical nature. They were considered to be chemically and biologically silised. They were characterised by a significant potential for soil enrichment in soil humus and biogenic elements. The content of heavy metals in the tested composts did not constitute a barrier to their use as a fertiliser. The contribution of carbon of humic substances (separated by $0.1 \mathrm{M} \mathrm{NaOH}$ ) ranged from 23.3 to $31.2 \%$. Among humic substances the most humic acids prevailed, with the ratio of humic to fulvic carbon from 2.07 to 3.03. The elemental composition of humic acids of the tested composts was similar to those occurring in humus horizons of intensively used arable soils. Spectrophotometric parameters indicated a low degree of their humification.

Keyw ords: compost, humic substances, humic acids
\end{abstract}

\section{INTRODUCTION}

The primary cause of deterioration of the fertility of soils and their reduced resistance to degradation is a decrease in the content of soil humus. In the case of soils of arable lands in Poland, the causes of reduced levels of humus include primarily the specialisation of production and the dominant share of plants with a negative organic matter balance in the structure of sowings (mainly cereals grown in monoculture), insufficient organic fertilisation (mainly due to manure deficit) and climate change leading to an intensification of mineralisation of soil organic matter (Gonet and Markiewicz 2007, Becher et al. 2013). Also highly important are 
the features of most of arable soils in Poland that are not conducive to a high level of humus accumulation. Those include primarily the particle size distribution (low content of clay fraction) and excessive acidification (leaching of alkaline components of low content of carbonates) (Karczewska 2012, Mocek 2015).

To ensure that soil performs possibly the best its production and environmental functions, one should aim at increasing the level of humus. In the context of improvement of the balance of soil organic matter, the importance of the so-called exogenic organic matter - formed outside of the soil environment but having a humus-forming potential - grows (Gonet and Markiewicz 2007, Maly and Siebielec 2015). In Poland, composts produced from the organic fraction of municipal waste are still an underestimated source of soil organic matter. As opposed to a majority of EU countries, such composts are used nearly exclusively in land reclamation and covering of waste dumps (Rosik-Dulewska 2015).

Minimisation of the amount of stored waste is a priority for modern waste management. In Poland, approximately 10.5 million tons of waste are produced per year, with a high (approx. 40\%) content of organic substance (Rosik-Dulewska 2015), and a growing interest is noted in composting as a method of recovery of wastes. The organic fraction of wastes is a potentially good material for composting, and the compost produced in the process allows the recovery of organic matter and the utilisation of nutrients in the production of biomass (Kucharczyk et al. 2010, Rosik-Dulewska 2015). In the case of the use of compost produced from wastes in food production (in agriculture and horticulture) it is necessary to eliminate threats that could have a negative effect on the natural environment and on the quality of yields. In this context it is very important to conduct research and monitoring of the properties of produced composts. Municipal wastes, and thus also composts produced from them, are characterised by varied chemical composition (including the amount and quality of organic matter and the content of heavy metals) (Drozd et al. 2003 and 2009, Ciesielczuk and Kusza 2009, Gondek and Kopeć 2012).

The study presented here addresses the problem of estimation of the properties of compost produced on the base of the organic fraction of municipal waste. The objective of the study was the characterisation of the chemical properties, including the quantity and quality traits of organic matter, of six composts originating from central-eastern Poland.

\section{MATERIAL AND METHOD}

The research material consisted of samples collected from mature compost storage sites at selected companies situated in central-eastern Poland, dealing with the collection and utilisation of municipal wastes (Siedlce, Włodawa, Opoczno, Warszawa, Wołomin, Radom). The process of composting was conducted in prisms 
in the open air, where the base of the composition of the composted mass were biodegradable municipal wastes (collected selectively and organic fractions from waste sorting facilities).

The following determinations were performed using samples of fresh material:

- measurement of $\mathrm{pH}$ value - with the potentiometric method, after sample flooding with $1 \mathrm{M} \mathrm{KCl}(\mathrm{v} / \mathrm{v}=1 / 2.5)$ (Hanna Instruments, $\mathrm{pH} 301)$;

- measurement of salinity - with the conductometric method, after sample flooding with $\mathrm{H}_{2} \mathrm{O}(\mathrm{v} / \mathrm{v}=1 / 2)$ (Hanna Instruments, $\left.\mathrm{HI} 2300\right)$;

- $\quad$ dry matter content (after drying at temperature of $105^{\circ} \mathrm{C}$ ).

For the remaining analyses the samples were dried at $40^{\circ} \mathrm{C}$, ground in a ceramic mortar, and screened through a sieve $(\varnothing 2 \mathrm{~mm})$. For the assay of chemical properties, a part of the dried material was ground in an agate mill (to particle size of $<0.25 \mathrm{~mm}$ ). The results of analyses of the chemical properties were referenced to absolutely dry matter of the prepared sample (silised after drying at $105^{\circ} \mathrm{C}$ ). The following laboratory analyses were performed (in 3 replicates):

- total content of carbon (TC) and nitrogen (TN) was assayed using a CHNS elemental analyser (Perkin Elmer, Series II 2400);

- content of $\mathrm{P}, \mathrm{K}$ and heavy metals $(\mathrm{Ni}, \mathrm{Pb}, \mathrm{Cd}$ and $\mathrm{Cr}$ ) was assayed using an ICP-AES atomic emission spectrometer (Perkin Elmer, Optima 3200 RL). Solutions for the assays were obtained after mineralisation in aqua regia;

- $\quad$ content of carbonates - with the Scheibler method.

Based on the amount of carbonates (mainly $\mathrm{CaCO}_{3}$ ), the amount of carbon representing mineral compounds (IC) was determined. The content of carbon in organic compounds (TOC) was calculated as follows: $\mathrm{TOC}=\mathrm{TC}-\mathrm{IC}$. The content of organic matter $(\mathrm{OM})$ was calculated as: $\mathrm{OM}=\mathrm{TC} \cdot 1.724$ (Bednarek et al. 2004);

Sequential fractionation of carbon compounds was performed (Dziadowiec and Gonet 1999, Becher 2013). The names and symbols of organic matter fractions and the method of their acquisition are presented in Table 1.

Preparations of humic acids were acquired with the use of alkaline extract $(0.1 \mathrm{M} \mathrm{NaOH})$. Gels of humic acids were acquired after acidification $(5 \mathrm{M} \mathrm{HCl}$, $24 \mathrm{~h}$ ), centrifuging and decantation of solution of fulvic acids. The preparation of humic acids preparations was conducted following the Schnitzer procedure (Dziadowiec and Gonet 1999). After drying in a vacuum desiccator (temp. $30^{\circ} \mathrm{C}$ ), the preparations were pulverised in an agate mortar and stored in an exsiccator (over concentrated $\mathrm{H}_{2} \mathrm{SO}_{4}$ ).

The following assays were performed for humic acids:

- elemental composition ( $\mathrm{C}, \mathrm{H}, \mathrm{N}, \mathrm{O})$. The content $\mathrm{C}, \mathrm{H}$ and $\mathrm{N}$ was assayed using an elemental auto-analyser with thermal conductivity detector (TCD) and acetanilide as standard material. The elemental composition was expressed in ash-free mass. Ash content was $0.97-1.31 \%$ (determined by 
weighing, after roasting at $550^{\circ} \mathrm{C}$ ). Oxygen content (in \%) was calculated as: $\mathrm{O}=100-(\mathrm{C}+\mathrm{H}+\mathrm{N})$. On the basis of the content of atoms of the elements, $\mathrm{H} / \mathrm{C}, \mathrm{N} / \mathrm{C}, \mathrm{O} / \mathrm{C}$ and $\mathrm{O} / \mathrm{H}$ ratios were calculated, as well as the degree of internal oxidation of molecules $(\omega=[(2 \mathrm{O}+3 \mathrm{~N})-\mathrm{H}] / \mathrm{C})($ Dębska 2004);

- spectrophotometric properties in VIS range, on a Lambda 25 spectrophotometer (Perkin Elmer), for $0.02 \%$ solutions of humic acids (in $0.05 \mathrm{M} \mathrm{NaHCO}_{3}$ ) at wavelengths (nm) of: 400 (A400), 465 (A465), 600 (A600) and 665 (A465). The absorbance ratio A4/6 (A4/6 = A465 / A665) and the parameter $\Delta \log \mathrm{K}(\Delta \log \mathrm{K}=\log \mathrm{A} 400-\log \mathrm{A} 600)$ were calculated (Chen et al. 1977, Kumada 1987).

The arithmetic mean values, minimum and maximum values, standard deviation (SD) and the coefficient of variation (CV) were calculated.

Table 1. Fractions of organic matter and methods of their acquisition

\begin{tabular}{|c|c|}
\hline Fraction name and symbol & Method of acquisition \\
\hline $\begin{array}{l}\text { Fraction after } \\
\text { decalcification } \\
\mathrm{C}_{\mathrm{DEC}}\end{array}$ & $\begin{array}{c}\text { Extraction } 0.05 \mathrm{M} \mathrm{H}_{2} \mathrm{SO}_{4} \text {; extraction time } 24 \mathrm{~h} ; \mathrm{m} / \mathrm{V}=1 / 25 \text {; centrifuging } \\
(\mathrm{g}=4000 \mathrm{rpm}) \text { and straining through cellulose filter. Carbon in solution } \\
\text { assayed with oxidation-titration method (Kalembasa 1991) }\end{array}$ \\
\hline $\begin{array}{l}\text { Fraction of bitumens } \\
\mathrm{C}_{\mathrm{BIT}}\end{array}$ & $\begin{array}{l}\text { Extraction (ethanol }+\mathrm{n} \text {-hexane, } \mathrm{v} / \mathrm{v}=1 / 1 \text { ) in automatic solvent } \\
\text { extraction apparatus Soxterm (Gerhard). Mass of bitumens determined } \\
\text { by weighing. Carbon in preparations assayed in elemental analyser }\end{array}$ \\
\hline $\begin{array}{l}\text { Fraction of humic } \\
\text { substances } \\
\mathrm{C}_{\mathrm{HS}}\end{array}$ & $\begin{array}{l}\text { Extraction } 0.1 \mathrm{M} \mathrm{NaOH} \text {; extraction time }=24 \mathrm{~h} ; \mathrm{m} / \mathrm{V}=1 / 25 \text {; } \\
\text { centrifuging }(\mathrm{g}=4000 \mathrm{rpm}) \text { and training through cellulose filter. Carbon } \\
\text { in solution assayed with oxidation-titration method. }\end{array}$ \\
\hline $\begin{array}{l}\text { Fraction of fulvic acids } \\
\mathrm{C}_{\mathrm{FA}}\end{array}$ & $\begin{array}{c}\text { Acidification }\left(2.5 \mathrm{M} \mathrm{H}_{2} \mathrm{SO}_{4}, \mathrm{pH}=1,80\right) \text { of measured part of extract } \\
0.1 \mathrm{M} \mathrm{NaOH} \text {. After precipitation and sedimentation of humic acids } \\
(24 \mathrm{~h}) \text {, carbon content in fulvic acids solution was assayed with } \\
\text { oxidation-titration method. }\end{array}$ \\
\hline $\begin{array}{l}\text { Fraction of humic acids } \\
\mathrm{C}_{\mathrm{HA}}\end{array}$ & Calculation: $\mathrm{C}_{\mathrm{HA}}=\mathrm{C}_{\mathrm{HS}}-\mathrm{C}_{\mathrm{FA}}$ \\
\hline Residual fraction $C_{R E S}$ & Calculation: $\mathrm{C}_{\mathrm{RES}}=\mathrm{TC}-\left(\mathrm{C}_{\mathrm{DEC}}+\mathrm{C}_{\mathrm{BIT}}+\mathrm{C}_{\mathrm{HS}}\right)$ \\
\hline
\end{tabular}

\section{RESULTS AND DISCUSSION}

\section{Basic properties of the composts}

The analysed composts were characterised by similar levels of dry matter content (average of 41.6\%) (Tab. 2). This is higher than that of most natural fertilisers and waste materials used in fertilisation (spent mushroom substrate, sewage sludge, fermentation residues) (Kalembasa et al. 2012, Becher and Pakuła 2014). 
Conductometric measurements in water solutions of the analysed composts ( 0.899 $1.20 \mathrm{mS} \mathrm{cm}^{-1}$ ) suggest low concentrations of soluble components (mainly ions), i.e. their low salinity.

Table 2. Values of descriptive statistics of selected properties of tested composts

\begin{tabular}{lccccc}
\hline \multicolumn{1}{c}{ Parameter } & Unit & Mean & Range & $\begin{array}{c}\text { Standard } \\
\text { deviation }\end{array}$ & $\begin{array}{c}\text { Coefficient of } \\
\text { variation (\%) }\end{array}$ \\
\hline pHKCl & & - & $7.20-7.67$ & - & - \\
Dry matter & $\%$ & 41.6 & $38.1-45.5$ & 2.58 & 6.11 \\
Salinity & $\mathrm{mS} \mathrm{cm}^{-1}$ & 1.04 & $0.899-1.20$ & 0.11 & 10.4 \\
$\mathrm{CaCO}_{3}$ & $\mathrm{~g} \mathrm{~kg}^{-1} \mathrm{~d} . \mathrm{m}$. & 35.4 & $19.3-41.8$ & 8.31 & 23.5 \\
$\mathrm{TC}$ & $\mathrm{g} \mathrm{kg}^{-1} \mathrm{~d} . \mathrm{m}$. & 168 & $142-193$ & 23.4 & 13.9 \\
$\mathrm{IC}$ & $\mathrm{g} \mathrm{kg}{ }^{-1} \mathrm{~d} . \mathrm{m}$. & 4.24 & $2.32-5.02$ & 1.00 & 23.5 \\
\hline
\end{tabular}

TC - Total carbon; IC - Inorganic carbon

In the analysed composts a significant amount of carbonates was noted, favourable in the context of their fertiliser use, with an average level of $35.4 \mathrm{~g} \mathrm{~kg}^{-1}$ (Tab. 2). In the case of the arable soils of Poland, apart from the need for humus reproduction, a fundamental task in activities aimed at improving soil fertility is the neutralisation of acidification (Karczewska 2012, Mocek 2015).

The observed high values of $\mathrm{pH}$ in $1 \mathrm{M} \mathrm{KCl} \mathrm{(7.20-7.67)} \mathrm{allow} \mathrm{the} \mathrm{analysed}$ materials to be classified as slightly alkaline. Generally, the results of laboratory analyses and the values of standard deviations calculated for the results suggest a similarity among the analysed composts that originated from various sources.

The calculated values of organic matter content, amounting to $240.9-325.5 \mathrm{~g} \mathrm{~kg}^{-1}$, do not allow to classify all of the analysed composts as organic fertilisers (Tab. 3).

Table 3. Content of organic matter and selected biogenic elements

\begin{tabular}{lccccccc}
\hline \multirow{2}{*}{ Compost No. } & OM & TOC & TN & $\mathrm{P}$ & $\mathrm{K}$ & \multirow{2}{*}{ TOC/TN } & TOC/P \\
\cline { 2 - 5 } 1 & 303.5 & 176.1 & 13.5 & 2.23 & 5.65 & 13.1 & 79.0 \\
2 & 240.9 & 139.8 & 9.63 & 3.07 & 2.40 & 14.5 & 45.6 \\
3 & 325.5 & 188.8 & 15.0 & 2.48 & 6.77 & 12.6 & 76.2 \\
4 & 247.6 & 143.6 & 11.4 & 2.08 & 5.37 & 12.6 & 68.9 \\
5 & 252.9 & 146.7 & 10.1 & 1.54 & 3.76 & 14.5 & 95.0 \\
6 & 322.4 & 187.0 & 15.8 & 2.43 & 7.10 & 11.8 & 77.1 \\
Mean & 282.1 & 163.7 & 12.6 & 2.30 & 5.18 & 13.2 & 73.6 \\
Standard & 39.3 & 22.8 & 2.58 & 0.50 & 1.80 & 1.11 & 16.2 \\
deviation & & & & & & & \\
Coefficient of & 13.9 & 13.9 & 20.6 & 21.8 & 34.8 & 8.40 & 22.0 \\
variation (\%) & & & & & & & \\
\hline
\end{tabular}


In conformance with the quality requirements given in the Regulation of the Minister of Agriculture and Rural Development of $18^{\text {th }}$ June 2008 (J. of Laws No. 119, item 765) to the Act in Fertilisers and Fertilisation (J. of Laws No. 147, item 1033), organic fertilisers should contain a minimum of $30 \%$ of organic substance, as converted to dry matter. At the same time, the observed levels of nitrogen, phosphorus and potassium are considerably higher than the limit values for organic fertilisers specified in the abovementioned Regulation (J. of Laws No. 119, item 765).

The content of the analysed biogenic elements in the composts under study was characterised by a fairly high variation - the highest in the case of potassium. The results indicate that the analysed composts should be considered as a significant source of biogenic elements.

The calculated values of $\mathrm{C} / \mathrm{N}$ ratio (mean of 13.2) and $\mathrm{C} / \mathrm{P}$ ratio (mean of 73.6) suggest a high degree of transformation of organic substance and stabilisation of the process of its degradation (Tab. 3). Generally, the values of those ratios indicate "maturity" of the analysed composts (Drozd et al. 2003 and 2009). In addition, the discussed quantitative ratios of $\mathrm{C}$ to $\mathrm{N}$ and $\mathrm{C}$ to $\mathrm{P}$ are similar to those found in the arable horizon of soils under intensive agricultural use and biologically active (Kalembasa and Becher 2009, Becher et al. 2013, Mocek 2015). The potential fertiliser use of compost will have no significant effect on a change in the quantitative relations of carbon, nitrogen and potassium in soil. One should, therefore, suppose that there will be no significant shift in the balance of transformations of those elements in the soil environment, in the direction of synthesis or mineralisation (Paul and Clark 1996, Kalembasa and Kalembasa 2015 and 2016). Similar quantitative ratios of carbon to nitrogen and phosphorus are noted in spent mushroom substrate (Kalembasa et al. 2012, Becher and Pakuła 2014).

The analysed composts were characterised by a varied content of heavy metals (Tab. 4).

Table 4. Content of heavy metals in the tested composts

\begin{tabular}{lcccccc}
\hline \multirow{2}{*}{ Compost No. } & $\mathrm{Zn}$ & $\mathrm{Cu}$ & $\mathrm{Pb}$ & $\mathrm{Cr}$ & $\mathrm{Ni}$ & $\mathrm{Cd}$ \\
\cline { 2 - 7 } & \multicolumn{7}{c}{$\mathrm{mg} \mathrm{kg}^{-1}$} & $\mathrm{~d} . \mathrm{m}$. \\
2 & 103.9 & 16.6 & 9.20 & 6.48 & 3.65 & 0.071 \\
2 & 199.1 & 44.6 & 15.3 & 12.3 & 8.58 & 0.719 \\
3 & 67.76 & 10.8 & 5.68 & 4.07 & 3.53 & 0.048 \\
4 & 98.94 & 17.3 & 6.68 & 4.85 & 3.83 & 0.063 \\
5 & 117.8 & 14.2 & 10.6 & 5.00 & 3.69 & 0.074 \\
6 & 153.3 & 25.0 & 10.1 & 6.94 & 5.23 & 0.103 \\
Mean & 123.5 & 21.4 & 9.60 & 6.60 & 4.75 & 0.179 \\
Standard deviation & 46.3 & 12.3 & 3.39 & 2.98 & 1.98 & 0.265 \\
Coefficient of variation (\%) & 37.5 & 57.4 & 35.3 & 45.2 & 41.7 & 147 \\
\hline
\end{tabular}


The assayed amounts of chromium, cadmium, nickel and lead are notably lower (by more than an order of magnitude) than those allowed by Polish law for fertilisers or plant cultivation augmenting agents that can be used as fertilisers in agriculture - those limit contents are ( $\mathrm{mg} \mathrm{kg}^{-1}$ d.m.): $\mathrm{Pb}-140 ; \mathrm{Cr}-100 ; \mathrm{Ni}-60$; Cd -5 (J. of Laws No. 119, item 765).

In general, analyzed composts were mainly different in terms of the content of elements associated with their mineral part (ash components), especially the metal content. This is probably the consequence of the diversity of organic materials used for composting in compost production sites.

Research shows that composts produced from municipal wastes can be an important source of microelements in soil. The observed levels of zinc and copper in the analysed composts fall within the quantity range encountered in the literature (Gondek and Filipek-Mazur 2005, Gondek 2006, Sądej and Namiotko 2011, Gondek and Kopeć 2012).

\section{Fractional composition of organic matter}

The fractional composition of organic matter of the analysed composts is presented as the contribution of carbon in the identified fractions (Tab. 5). They can be arranged in the following sequence of increasing quantitative importance: $\mathrm{C}_{\mathrm{DEC}}<$ $\mathrm{C}_{\mathrm{BIT}}<\mathrm{C}_{\mathrm{KF}}<\mathrm{C}_{\mathrm{KH}}<\mathrm{C}_{\mathrm{RES}}$. Among the identified fractions, the greatest variation was characteristic of the fractions after decalcification, bitumens, and that of fulvic acids.

Table 5. Values of descriptive statistics of fractional composition of organic matter of tested composts $(\%$ TOC)

\begin{tabular}{ccccc}
\hline Parameter & Mean & Range & Standard deviation & $\begin{array}{c}\text { Coefficient of } \\
\text { variation (\%) }\end{array}$ \\
\hline $\mathrm{C}_{\mathrm{DEC}}$ & 1.29 & $1.01-2.05$ & 0.390 & 30.2 \\
$\mathrm{C}_{\mathrm{BIT}}$ & 3.45 & $2.53-4.49$ & 0.790 & 22.4 \\
$\mathrm{C}_{\mathrm{HS}}$ & 26.7 & $23.3-31.2$ & 2.74 & 10.2 \\
$\mathrm{C}_{\mathrm{FA}}$ & 7.59 & $6.28-10.2$ & 1.38 & 17.9 \\
$\mathrm{C}_{\mathrm{HA}}$ & 19.1 & $16.4-20.9$ & 1.78 & 9.30 \\
$\mathrm{C}_{\mathrm{RES}}$ & 68.6 & $62.5-72.8$ & 3.73 & 5.44 \\
$\mathrm{C}_{\mathrm{KH}} / \mathrm{C}_{\mathrm{KF}}$ & 2.56 & $2.07-3.03$ & 0.370 & 14.4 \\
\hline
\end{tabular}

$\mathrm{C}_{\mathrm{DEC}}-$ Fraction of carbon after decalcification; $\mathrm{C}_{\mathrm{BIT}}-$ Carbon of bitumens; $\mathrm{C}_{\mathrm{HS}}-$ Carbon of humic substances; $\mathrm{C}_{\mathrm{FA}}-$ Carbon of fulvic acids; $\mathrm{C}_{\mathrm{HA}}-$ Carbon of humic acids; $\mathrm{C}_{\mathrm{RES}}-$ Carbon of residual fraction

The fraction separated by $0.05 \mathrm{M} \mathrm{H}_{2} \mathrm{SO}_{4}\left(\mathrm{C}_{\mathrm{DEC}}\right)$ was characterised by the lowest level of contribution (Tab. 5). It was represented mainly by simple low-molecular organic compounds, free and weakly bound with the mineral components of the analysed material. After fertiliser application, those compounds are the most labile in the soil environment, with a relatively short period of persistence in the 
soil (Stevenson 1985, Turski 1988, Dębska 2004). The small content of that fraction can indicate stability of organic compounds present in the analysed composts (Drozd et al. 2003 and 2009). Spent mushroom substrate has a considerably higher content of that fraction (Kalembasa et al. 2012, Becher and Pakuła 2014).

Organic solvents isolated a small amount (mean of $3.45 \%$ ) of carbon resources $\left(\mathrm{C}_{\mathrm{BIT}}\right)$ from the analysed composts (Tab. 5.). The bitumens fraction (lipid) is a highly diversified group of organic compounds, that include e.g. waxes, tars, resins, fatty acids and their esters, and many other compounds with aliphatic character and a high energy value (Becher and Kalembasa 2006, Neves et al. 2009). Generally, the oxygen degradation of organic matter, characteristic for the process of composting, high biological activity and richness in elements with alkaline character (participating in reactions of lipids saponification) are not conducive to the accumulation of lipid substances (Turski 1988, Wiesenberg et al. 2004, Becher and Kalembasa 2006, Kalembasa and Becher 2009).

Apart from the processes of mineralisation of organic matter, another characteristic process taking place during composting is the synthesis of humic substances in the process of humification. Conventionally, those substances are isolated through extraction with alkaline solutions. From the analysed composts we isolated $(0.1 \mathrm{M} \mathrm{NaOH})$ from 23.3 to $31.2 \%$ of carbon representing humic substances $\left(\mathrm{C}_{\mathrm{HS}}\right)$ (Tab. 5). Among those substances, the more stable humic acids $\left(\mathrm{C}_{\mathrm{HA}}\right)$ decidedly dominated over the labile and more reactive fulvic acids $\left(\mathrm{C}_{\mathrm{FA}}\right)$. This was reflected in the value of the ratio of carbon of humic acids to that of fulvic acids $\left(\mathrm{C}_{\mathrm{HA}} / \mathrm{C}_{\mathrm{FA}}\right)$, varying in the range of 2.07-3.03. The value of that parameter is another trait that can indicate stabilisation of the processes of degradation and an advanced process of humification in the analysed materials. According to numerous researchers (Kalembasa 2000, Veeken et al. 2000, Dębska 2004, Dębska et al. 2009), with the progress of the process of humification of "fresh" organic substance the importance of the contribution of the fraction of humic acids increases. A distinct domination of humic acids is an important quality feature of humus in arable soils, as it indicates humus stabilisation and a favourable and stable effect on the physical and physicochemical properties of soils (Stevenson1985, Turski 1988, Becher et al. 2013, Mocek 2015).

In the analysed composts, carbon of the residual fraction $\left(\mathrm{C}_{\mathrm{RES}}\right)$ constituted approximately $2 / 3$ of the total resources of organic carbon (Tab. 5). One should suppose that in the analysed materials, apart from the most stable humic substances, a considerable part of that fraction consists of non-humified organic compounds - the most resistant to microbiological degradation (mainly cellulose, hemicellulose, lignins), genetically related to the material used in the compost production. Due to the lack of clay minerals, very stable complexes of humic substances with mineral components are rather rarely encountered in composts (Stevenson 1985, Turski 1988, Mocek 2015). 


\section{Properties of humic acids}

In the opinion of many authors (Stevenson 1985, Turski 1988, Senesi et al. 2003, Szombathová et al. 2004, Kalembasa and Becher 2009), humic acids constitute one of the most interesting and researched fractions of humus - they are characterised by relatively stable properties and determine the physical and chemical properties of soils.

In the analysed composts, as demonstrated in the fractional composition of organic matter, humic acids account for about $1 / 5$ of the total resources of organic matter. The elemental composition (\% atomic) obtained in the study is similar to that found in humic acids isolated from the arable-humus horizons of soils under intensive agricultural use (Turski 1988, Senesi et al. 2003, Szombathová et al. 2004, Kalembasa and Becher 2009, Becher et al. 2013). Generally, the obtained results of qualitative analyses of humic acids suggest that, irrespective of their origin, they display a similarity of chemical structure, which is particularly indicated by the atomic ratios and the spectrophotometric properties (Tab. 6).

Table 6. Values of descriptive statistics of properties of humic acids isolated from the tested composts

\begin{tabular}{|c|c|c|c|c|}
\hline Parameter & Mean & Range & Standard deviation & $\begin{array}{l}\text { Coefficient of } \\
\text { variation }(\%)\end{array}$ \\
\hline \multicolumn{5}{|c|}{ elemental composition ( $\%$ atomic) } \\
\hline $\mathrm{C}$ & 36.5 & $35.7-37.3$ & 0.593 & 1.62 \\
\hline $\mathrm{H}$ & 39.7 & $38.6-41.3$ & 1.04 & 2.62 \\
\hline $\mathrm{N}$ & 2.80 & $2.18-3.16$ & 0.358 & 12.8 \\
\hline \multicolumn{5}{|c|}{ atomic ratios } \\
\hline $\mathrm{H} / \mathrm{C}$ & 1.09 & $1.03-1.15$ & 0.045 & 4.10 \\
\hline $\mathrm{N} / \mathrm{C}$ & 0.077 & $0.060-0.088$ & 0.010 & 13.1 \\
\hline $\mathrm{O} / \mathrm{C}$ & 0.576 & $0.544-0.593$ & 0.018 & 3.17 \\
\hline $\mathrm{O} / \mathrm{H}$ & 0.529 & $0.473-0.556$ & 0.030 & 5.70 \\
\hline \multicolumn{5}{|c|}{ degree of internal oxidation of molecules } \\
\hline$\omega$ & 0.292 & $0.202-0.361$ & 0.057 & 19.6 \\
\hline \multicolumn{5}{|c|}{ spectrophotometric parameters } \\
\hline $\mathrm{A} 4 / 6$ & 6.56 & $5.17-7.32$ & 0.737 & 11.2 \\
\hline$\Delta \log K$ & 0.811 & $0.771-0.859$ & 0.034 & 4.20 \\
\hline
\end{tabular}

$\omega$ - Degree of internal oxidation of molecules; A4/6 - Absorbance ratio (A465/A665); $\Delta \operatorname{logK}=$ $\log \mathrm{A} 400-\log \mathrm{A} 600$

The obtained values of $\mathrm{H} / \mathrm{C}(1.03-1.15)$ indicate that the structure of the analysed humic acids corresponds to aromatic systems coupled with an aliphatic chain containing up to 10 atoms of carbon (Visser 1983). H/C values higher than one may 
indicate a domination of aliphatic structures, but also suggest a significant contribution of aromatic structures in the molecules of the analysed humic acids (Turski 1988, Amir et al. 2010).

For the analysed humic acids positive values of the degree of internal oxidation of molecules $(\omega)$ were obtained. That parameter, and the values of the atomic ratios $\mathrm{O} / \mathrm{C}$ and $\mathrm{O} / \mathrm{H}$, suggest that the synthesis of the humic acids took place under conditions of good oxygenation (Veeken et al. 2000, Amir et al. 2010).

In this study fairly high values of the quotient of absorbance (A4/6) were obtained. They indicate a rather low "maturity" of humic acids, and suggest their low molecular weight and low condensation of aromatic centres (Chen et al. 1977, Howarda et al. 1988, Senesi et al. 2003). In correspondence to the values of A4/6, also the mean value of coefficient $\Delta \log \mathrm{K}$ indicates a rather low degree of their humification (Kumada 1987). In accordance with Kumada's classification proposal (1987), the obtained values of parameter $\Delta \operatorname{logK}$ allow to classify the analysed humic acids at the boundary of type $\mathrm{B}$ (medium degree of humification $-\Delta \log \mathrm{K}$ in the range of 0.6-0.8) and type $\mathrm{R}$ (low degree of humification $-\Delta \log \mathrm{K}$ values in the range of $0.8-1.1$ ). Compared to humic acids of arable soils, for the analysed humic acids a similar elemental composition was obtained, as well as values of atomic ratios, and higher values of spectrophotometric parameters (Dębska et al. 2009, Kalembasa and Becher 2009, Becher et al. 2013).

\section{CONCLUSIONS}

1. The analysed composts, produced from municipal wastes, were characterised by a similarity of their chemical nature. The composts should be considered to be chemically and biologically stabilised, and containing organic matter transformed to a notable degree in the process of humification.

2. Humic acids of the analysed composts were considered to be insufficiently mature, i.e. characterised by a low content and low condensation of aromatic centres, a high level of aliphatic structures, low molecular weight and probably weak binding with the mineral fraction of the analysed materials.

3. Heavy metals contained in the analysed composts do not constitute a barrier to fertiliser use and do not pose a threat to the natural environment. The notable content of stable humic substances and low content of labile forms of organic matter, alkaline reaction and presence of carbonates, contribute to the immobilisation of heavy metals in the analysed composts.

4. The analysed composts have a considerable potential for enriching soils in soil humus and biogenic elements. Their use as fertiliser will contribute to a relatively rapid increase and stabilisation of the content of humus in soil. 


\section{REFERENCES}

Amir S., Jouraiphy A., Meddich A., El Gharous M., Winterton P., Hafidi M., 2010. Structural study of humic acids during composting of activated sludge-green waste: Elemental analysis, FTIR and 13C NMR. Journal of Hazardous Materials, 177(1-3), 524-529, doi:10.1016/j.jhazmat.2009.12.064

Becher M., 2013. State of transformation of organic matter of soils of the valley of upper river Liwiec (in Polish). Rozprawa naukowa nr 125, UPH w Siedlcach, 158.

Becher M., Kalembasa D., 2006. Characterisation of bitumens of forest cambic arenosols and podzolic soils in the South Podlasoe Lowland (in Polish). Rocz. Glebozn., 57(3-4), 5-12.

Becher M., Kalembasa D., Pakuła K., Malinowska E., 2013. Resources and quality of organic matter in arable grey-brown podzolic soils of Siedlecka Upland (in Polish). Acta Sci. Pol. Agricultura., 12(4), 7-17.

Becher M., Pakuła K., 2014. Nitrogen fractions in spent mushroom substrate. J. Elem., 19(4), 947958, doi:10.5601/jelem.2014.19.2.330

Bednarek R., Pokojska U., Dziadowiec H., Prusinkiewicz Z., 2004. Ecological-soil science studies (in Polish). Wyd. PWN, Warszawa.

Chen Y., Senesi N., Schnitzer M., 1977. Information provided on humic substances by E4/6 ratios. Soil Sci. Soc. Am. J., 41, 352-358, doi:10.2136/sssaj1977.03615995004100020037x

Ciesielczuk T., Kusza G., 2009. Content of heavy metals in composts produced from wastes as a factor limiting their use for fertilisation purposes (in Polish). Ochr. Erod. Zas. Natur., 41, 347-353.

Dębska B., 2004. Properties of humus substances of soil fertilised with liquid manure (in Polish). Rozprawy ATR Bydgoszcz, 110.

Dębska B., Szombathová N., Banach-Szott M., 2009. Properties of humic acids of soil under different management regimes. Pol. J. Soil Sci., 42(2), 131-138.

Drozd J., Linczar M., Bekier J., 2009. Estimation of maturity of composts from municipal waste on the basis of quality of humus compounds and various forms of nitrogen (in Polish). Rocz. Gleb., 60(3), 67-74.

Drozd J., Linczar M., Jamroz E., Bekier J., 2003. Humic indicators of compost maturity (in Polish), In: Humus substances in soils and fertilisers (Eds B. Dębska, S. Gonet). Polskie Towarzystwo Substancji Humusowych, Wrocław.

Dziadowiec H., Gonet S.S., 1999. A methodological guide to the study of organic matter of soils (in Polish). Prace Komisji Naukowych PTG 120, Warszawa.

Gondek K., 2006. Content of various forms of heavy metals in sewage sludge and composts (in Polish). Acta Agroph., 8(4), 825-838.

Gondek K., Filipek-Mazur B., 2005. Agrochemical estimation of fertiliser value of composts of various origins (in Polish). Acta Agroph., 5(2), 271-282.

Gondek K., Kopeć M., 2012. Content of selected macro and microelements in composted biodegradable municipal wastes (in Polish). Acta Agroph., 19(3), 527-538.

Gonet S., Markiewicz M., 2007. Role of organic matter in the environment (in Polish). PTSH, Wrocław.

Howarda P.J.A., Howarda D.M., Loweb L.E., 1988. Effects of tree species and soil physico-chemical conditions on the nature of soil organic matter. Soil Biol. Bioch., 30(3), 285-297, doi:10.1016/ S0038-0717(97)00138-7

Kalembasa D., 2000. Characterisation of vermicomposts and their transformations in sandy formations (in Polish). Rozprawy AP w Siedlcach.

Kalembasa D., Becher M., 2009. Properties of organic matter in chosen soils fertilized with sewage sludge. Environ. Prot. Eng., 35(2), 165-171.

Kalembasa D., Becher M., Bik B., Makolewski A., 2012. Properties of organic matter of spent mushroom substrate (in Polish). Acta Agroph., 2012, 19(4), 713-723. 
Kalembasa S., 1991. Quick method of determination of organic carbon in soil. Pol. J. Soil Sci. 24(1), 17-22.

Kalembasa S., Kalembasa D., 2015. Soil chemistry and biochemistry (selected topics) (in Polish). Wyd. UPH w Siedlcach.

Kalembasa S., Kalembasa D., 2016. Conversions and pathways of organic carbon and organic nitrogen in soils. In: Bioactive Compounds in Agricultural Soils (Ed. L.W. Szajdak). Springer International Publishing Switzerland. ttps://doi.org/10.1007/978-3-319-43107-9_3

Karczewska A., 2012. Protection of soils and reclamation of degraded areas (in Polish). Wyd. UP we Wrocławiu.

Kucharczyk K., Stępień W., Gworek B., 2010. Composting of municipal wastes as a method of recovery of organic matter (in Polish). Ochr. Środ. Zas. Natur., 41, 240-254.

Kumada K., 1987. Chemistry of soil organic matter. Elsevier, Amsterdam-Oxford-New York-Tokyo.

Maly S., Siebielec G., 2015. Analysis of exogenic organic matter aimed at its safe application to soil (in Polish). Centralny Instytut Badań i Nadzoru w Rolnictwie, Brno.

Mocek A., 2015. Soil science (in Polish). Wyd. Nauk. PWN, Warszawa.

Neves L., Ferreira V., Oliveira R., 2009. Co-composting cow manure with food waste: The influence of lipids content. World Acad. Sci., Eng. \& Technol., 58, 986-991.

Paul E.A., Clark F.E., 1996. Soil microbiology and biochemistry. Academic Press, San Diego.

Rosik-Dulewska Cz., 2015. Fundamentals of waste management (in Polish), Wydawnictwo Naukowe PWN, Warszawa.

Regulation of the Minister of Agriculture and Rural Development of $18^{\text {th }}$ June 2008. Journal of Laws No. 119, item 765.

Sądej W., Namiotko A., 2011. Content of copper, zinc and manganese in soil fertilized with municipal solid waste composts. Ecol. Chem. Eng, A(18), 9-10.

Senesi N., D’Orazio V., Ricca G., 2003. Humic acids in the first generation of EUROSOILS. Geoderma, 116, 325-344, doi:10.1016/S0016-7061(03)00107-1

Stevenson F.J., 1985. Geochemistry of Soil Humic Substances. In: Humic Substances in Soil, Sediment and Wate. John Wiley and Sons, New York, 13-53.

Szombathová N., Dębska B., Lacko-Bartošová M., Zaujec A. Gonet S., 2004. Characteristics of humic acids isolated from soils under various farming systems. Acta Sci. Pol., Agricult., 3(2), 37-45.

Turski R., 1988. Characteristics of humic compounds in soil of Poland (in Polish). PWN, Warszawa.

Veeken A., Nierop K., de Wilde V., Hamelers B., 2000. Characterization of NaOH-extraction humic acids during composting of biowaste. Bioresource Technol., 72(1), 33-41, doi:10.1016/ S0960-8524(99)90096-2

Visser S.A., 1983. Application of van Krevelen's graphical statistical method for the study of aquatic humic material. Environ. Sci. Techn., 17(7), 412-417, doi:10.1021/es00113a010

Wiesenberg G.L.B., Schwark L., Schmidt W.I., 2004. Improved automated extraction and separation procedure for soil lipid analyses. Eur. J. Soil Sci., 55, 349-356, doi:10.1111/ j.1351-0754.2004.00601.x 


\title{
WŁAŚCIWOŚCI CHEMICZNE KOMPOSTÓW Z ODPADÓW KOMUNALNYCH W KONTEKŚCIE NAWOZOWEGO WYKORZYSTANIA
}

\author{
Marcin Becher, Barbara Symanowicz, Dawid Jaremko, Ewa Trzcińska
}

Zakład Gleboznawstwa i Chemii Rolniczej, Uniwersytet Przyrodniczo-Humanistyczny w Siedlcach ul. Konarskiego 2, 08-110 Siedlce

e-mail: marcin.becher@uph.edu.pl

Streszczenie. W pracy naukowej podjęto problem badawczy oceny właściwości chemicznych, w tym ilości i jakości materii organicznej, kompostu produkowanego na bazie frakcji organicznej odpadów komunalnych. Badaniami objęto sześć kompostów pochodzących ze środkowo-wschodniej Polski. Wykonano następujące analizy: odczyn, zasolenie, zawartość węglanów, zawartość C, N, P, $\mathrm{K}$, metali ciężkich, skład frakcyjny materii organicznej (frakcje: po dekalcytacji, bituminów, kwasów fulwowych, kwasów huminowych i poekstrakcyjna pozostałość) oraz właściwości kwasów huminowych (skład elementarny i właściwości spektrofotometryczne). Badane komposty charakteryzowały się podobieństwem natury chemicznej. Uznano je za ustabilizowane chemicznie i biologicznie. Odznaczają się one znacznym potencjałem wzbogacania gleb w próchnicę glebową i pierwiastki biogenne. Metale ciężkie zawarte w badanych kompostach nie stanowiły bariery przy nawozowym wykorzystaniu. Udział węgla substancji humusowych (wydzielonych 0,1 $\mathrm{M} \mathrm{NaOH}$ ) wynosił 23,331,2. Wśród substancji humusowych zdecydowanie przeważały bardziej stabilne kwasy huminowe, przy stosunku węgla kwasów huminowych do fulwowych od 2,07 do 3,03. Skład elementarny kwasów huminowych badanych kompostów był zbliżony do występujących w poziomach próchnicznych intensywnie użytkowanych gruntów ornych. Parametry spektrofotometryczne świadczyły o małym stopniu humifikacji kompostów.

Słowa kluczowe: kompost, substancje humusowe, kwasy huminowe 